\title{
GUSTAV VILBASTE KUI ETNOBOTAANILISE AINESE KOGUJA, UURIJA JA PUBLITSEERIJA
}

\author{
RAIVO KALLE, \\ RENATA SÕUKAND
}

\begin{abstract}
Annotatsioon. Gustav Vilbaste teened eestikeelse botaanika kujunemisel on märkimisväärsed. Tema ajal töötati rahvapäraste taimenimede põhjal välja ametlikud botaanikaterminid, muud rahva seas kasutusel olnud nimed jäid aga rahvaluule valdkonda. Vilbastest sai selle valdkonna parim tundja Eestis. Siiani pole väärilist tähelepanu pööratud Vilbaste panusele etnobotaanika kui teaduse kujundamisse Eestis, seda enam, et tema suure töö tulemusena meieni jõudnud taimepärimuskogule mujal maailmas võrdväärset leida on raske. Kuni ülikooli astumiseni kogus Vilbaste rahvapärimust, eelkõige rahvalaule, peamiselt ise. Kõige viljakam etnobotaanilise ainese kogumise, uurimise ja publitseerimise periood jääb ajavahemikku 1920-1940, mil ta kaastööliste abiga kogus enamiku oma etnobotaanikat sisaldavast käsikirjakogust. See kogu sisaldab üksi pea sama palju taimepärimust, kui leidub teistes Eesti Kirjandusmuuseumi Eesti rahvaluule arhiivi kogudes kokku. Vanaduspensionil olles pöördus Vilbaste tagasi rahvapärimuse kogumise juurde ja käis ka mitmetel välisekspeditsioonidel eesti hõimlaste juures.
\end{abstract}

Võtmesõnad: eesti keel, murdekogumine, etnobotaanika, taimenimed

\section{Sissejuhatus}

Termini etnobotaanika formuleeris esimest korda Ameerika Ühendriikide botaanik John William Harshberger aastal 1895 ja see tähistas pärismaalaste taimekasutust. Tänapäeval mõeldakse etnobotaanika all interdistsiplinaarset teadusharu, mis uurib taimede kohta käivaid teadmisi ja nende kasutust tavainimeste hulgas. Kuigi etnobotaanika on teadusharuna võrdlemisi noor, on seda valdkonda Euroopas uuritud juba sajandeid (Svanberg jt 2011). Eestis tuntakse etnobotaanikat teadusharuna vähe ja selle tõsiselt võetavatest esindajatest võibki nimetada vaid ühte - Gustav Vilbastet. 
Filoloog-ornitoloog Mart Mäger on Vilbaste rahvapärimuse kogumise jaganud aktiivsuse järgi kolme perioodi. Selline aktiivsust arvestav liigitus sobib hästi iseloomustama ka Vilbaste etnobotaanilist tegevust. Esimene periood noorukieast (u 1902) kuni ülikooli astumiseni (umbes 1919) oli iseõppimise ja omal käel pärimuse kogumise aeg. Sel ajal oli Vilbastel huvi rohkem keele, murde ja etnograafia vastu. Teise etapi alguseks saaks tinglikult olla tema esimeste üleskutsete ilmumise aeg ajakirjanduses (1923) kuni II maailmasõja lõpuni (1945). Vilbaste selleaegsed huvid olid seotud eelkõige botaanika ja looduskaitsega, etnobotaanilise pärimuse kogumisel ilmutas ta suurt professionaalsust. Sõjajärgsest ajast alates nihkusid Vilbaste huvid tagasi murde- ja koduloouurimisele (v.a lühike aeg Loodusmuuseumis botaanikuna töötades), sest nagu ta on märkinud: „/---/ botaanikas ei suuda ma enam kuigi palju saavutada, sest vaated botaanika kui teaduse peale olid muutunud /---/; noored botaanikud olid loonud uued meetodid taimkatte uurimises ja ma ei oleks suutnud siin töötada täie innuga" (Mäger 1967: 121).

Käesolevas artiklis kirjeldatakse Gustav Vilbaste (1885-1967, kuni 1935. aastani Vilberg) kujunemist etnobotaanikuks, analüüsitakse Vilbaste etnobotaanilise ainese kogumise meetodeid ning tema etnobotaanilisi artikleid ja raamatuid, mis artikli autoreile teada olid. Samuti käsitletakse Vilbaste käsikirjakogu, mis asub Eesti Kirjandusmuuseumis Eesti rahvaluule arhiivis (ERA) temanimelises kogus (Vilbaste). See on kogutud ja koostatud aastatel 1907-1966 ning sisaldab 20327 lehekülge 42 köites. Artikli kirjutamisel ei ole kasutatud Vilbaste ligi pooleteisetuhande kirjega bibliograafiat, mis leiti hiljuti Emakeele Seltsist.

\section{Kodumurrete kogumine ja esimesed sammud etnobotaanikas ${ }^{1}$}

Huvi rahvaluule vastu tekkis Vilbastel juba lapsepõlves. Ta on meenutanud, et kodus kõneldi kolme keelt: ema kõneles maakeelt, isa kõneles rannakeelt ja teenijatüdruk, kes oli pärit Kolgast, Kolga keelt. Lisaks veel isapoolne vanaema, kes kõneles hoopis põhiranna keelt. Selline murrakute erinevus hakkas talle tollal kohe kõrva (Vilbaste 1965). Noorukieas hakkas Vilbaste

Vilbaste rahvaluule, peamiselt küll rahvalaulude kogumist kuni 1916. aastani on põhjalikult uurinud etnomusikoloog Janika Oras (2006). Oma esimestest sammudest rahvaluule kogumisel ja neid mõjutanud teguritest on Vilbaste kirjutanud Emakeele Seltsi väljaandes Kodumurre (1965). 
omal käel neid eri murrakus räägitud jutte kirja panema. Esimesed saadetised kodukoha muistenditega kandsid saatmiskuupäeva 20. september 1902. Need olid läkitatud tolleaegsele muistendite suurkogujale Matthias Johann Eisenile (Hiiemäe 2005).

Vilbaste kiindumust oma kodukohta, mida võib laiendada kogu IdaHarjumaale, näitab see, et tast kujunes viljakaim kaastööline rahvalaulude kogumise alal Oskar Kalda üleskutsel Eesti Üliõpilaste Seltsi (EÜS) kaudu (aastatel 1910-1914) ja tähelepanuväärse koguse etnograafilise materjali koguja Eesti Rahva Muuseumile (aastatel 1910-1911) (Laasimer jt 1994; Mäger 1967).

Vilbaste suurimaks kireks ja hobiks kuni elupäevade lõpuni said rahvapärased taimenimed. Süsteemset kogumist alustas Vilbaste 1907. aastal EÜSi korraldatud üleriigiliste rahvapäraste taimenimede kogumise aktsioonide ajal (vt nt Postimees 1907, 1912). EÜSi kogumisaktsiooni eesmärk oli rahvapäraste taimenimede põhjal moodustada ühtne, binaarset süsteemi arvestav taimede nimekiri.

Vilbastest kujunes üks suuremaid taimenimede saatjaid EÜSi üleskutsete peale. Kuigi tal puudus botaanikuharidus, oli tal suur iseõppimisvõime ja ta suutis välitöödel kohatud taimi omal käel määrata, kasutades selleks botaanik Heinrich Moritz Willkommi taimeatlase venekeelset tõlget (Laasimer jt 1994). 1915. aastal julges Vilbaste juba Eesti Kirjanduse veergudel arutleda vetika Fucus vesiculosus (põisadru) etümoloogia ja kasutuse üle ning mis peamine, andis soovituse kasutada selle vetika puhul nimetust atru, adru, mitte muda, nagu seda oli seni kirjanduses tuntud. Sama aastal ilmunud jätkuartikliks oli Vilbaste teinud juba põhjaliku uurimuse ning küsitlenud rannaäärseid õpetajaid näitamaks, et tema pakutud nimi on sobivaim (Vilberg 1915a, 1915b). Säilinud on ka Vilbaste küsitlusele saadetud vastus kooliõpetajalt V. Ojalt (Vilbaste, TN 1: 1043). Võib öelda, et need olid esimesed etnobotaanilised uurimused, mis andsid oma panuse ka botaanika sõnavarra.

Esialgne taimede nimekiri avaldati pärast EÜSi ja Eesti Kirjanduse Seltsi (EKS) pikki töökoosolekuid alles 1917. aastal ajakirja Eesti Kirjandus lisana, millele oli lisatud palve täienduste ja paranduste kohta. Brošüüri eessõnas mainitakse Vilbastet ja veel kolme korrespondenti kui eriti väärtusliku materjali saatjaid (KT 1917). Ka sellele üleskutsele nimekirja täiendada ja parandada Vilbaste reageeris ning tema panus märgitakse ära 1918. aastal ilmunud täiendatud väljaande „Kodumaa taimede" eessõnas (KT 1918). 


\section{Koguja ja korrespondentide võrgu hoidja alates 1920ndatest}

1920. aastal loodi Emakeele Selts, mille liikmeks Vilbaste kohe astus. See suurendas Vilbaste professionaalsust murdekogumisel ja -uurimisel, eeskätt rahvapäraste taimenimede kogumisel.

Murrangu etnobotaanilise ainese kogumisse tõid 1923. aastal üleskutsed üleriigilise levikuga perioodikas: Vikerkaares (Vilberg 1923a), Eesti Metsas (Vilberg 1923b), Looduses (Vilberg 1923c) ja Kasvatuses (Vilberg 1923d). Esimestes üleskutsetes piirduvad kaastöölistele esitatud nõuded rahvapäraste taimenimetuste hilisemaks tuvastamiseks vaid ladina-, saksa- või venekeelse nime juurdelisamisega. Lisaks soovitab Vilbaste taimede määramisel kasutada oma aasta tagasi ilmunud määrajat (Vilberg 1922). Üleskutsete lõpus esitab ta ka esimese aruande ja nimetab selles juba kahte kirjasaatjat. Selle üleskutse avaldas lühendatult ka ajaleht Postimees (1923). Nii neis kui ka järgnevates üleskutsetes rõhutab Vilbaste, et taimepärimus on hävimas ja kadumas ning sellepärast tuleb see tarkus kokku koguda. Ta lisas, et kavatseb edaspidi seda teavet kasutada Eesti kõigi „rahva suus tuntud nimede” nimestiku väljaandmiseks.

Oma üleskutset kordas ta alles pea viie aasta pärast ajakirjades Eesti Keel (Vilberg 1928a), Eesti Kirjandus (Vilberg 1928b), Noorusmaa (Vilberg 1928e) ning ka laia lugejaskonnaga ajalehtedes Postimees (Vilberg 1928c) ja Päevaleht (Vilberg 1928d). Ajakirjas Noorusmaa avaldab ta koos üleskutsega oma noorusajal kodukohas kuuldud rahvapäraste taimenimede loendi, milles on kokku 215 liiki. Vilbaste tõdeb selles artiklis, et enamasti tunnevad õpilased 50-100 taime; üle 100 teavad üksikud, kellel on botaaniline huvi (Vilberg 1928f).

Kohe järgmisel aastal avaldas Vilbaste ajakirjas Eesti Mets (Vilberg 1929a) ja ajalehes Postimees (Vilberg 1929b) juba täiendatud küsimustiku, kus rõhuasetus oli taimenimedelt läinud taimekasutuse kogumisele. Seal esitas ta eraldi järgmisi küsimusi: missuguse nime all taimi tuntakse, milleks endisel ajal taimi tarvitati (arstirohuks, värvimiseks, nõidusvahendiks, toiduks jne), missuguseid muinasjutte tuntakse taimede kohta, missuguseid töid ja toimetusi seatakse ühendusse taime õitse-, valmimisajaga. Selles üleskutses olid kaastöölistele esitatud nõuded läinud karmimaks. Nüüd tahtis Vilbaste eestikeelse ja ladinakeelse nime kõrvale ka taimenäidist ehk herbaarlehte. Kui palju talle herbaarlehti saadeti, pole tagantjärele võimalik öelda, sest ta liitis need oma herbaariumiga. Viimases oli kokku ligi 14000 eksemplari herbaarlehte ja need on tänaseks liidetud Eesti 
Maaülikooli põllumajandus- ja keskkonnainstituudi Eesti soontaimede herbaariumiga. Väikeseid taimenäidiseid, mis kirjasaatjad olid kleepinud pärimustekstide kõrvale, on käsikirjakogus säilinud üksjagu. Mõni kirjasaatja on lisanud taimede paremaks äratundmiseks ka taimejooniseid. Üleskutses märgib Vilbaste, et taimede määramisel võib kasutada tema 1925. aastal ilmunud täiendatud ja ümbertöötatud taimemäärajat (Vilberg 1925). Üleskutse ajal ilmus oluline teos Eesti botaanika ajaloos: „Kodumaa taimede” teine, täiesti ümbertöötatud trükk pealkirjaga ,Eesti taimede nimestik" (Nenjukov 1928), mille avaldamisel olid Vilbastel märkimisväärselt suured teened. Võib öelda, et selle nimekirja ilmumisega võeti kasutusele ja kinnistus enamik tänaseni püsima jäänud ühtsetest eestikeelsetest taimenimedest.

Järgmise üleskutse koos aruandega avaldasid kaks aastat hiljem ajakiri Eesti Kirjandus (Vilberg 1930a) ja ajaleht Postimees (Vilberg 1930b). Vilbaste alustas oma aruannet järgmiselt: „Kirjakeel tungib igal teadusealal suure jõuga peale ja hävitab hoolimatult rahvapärasuse mõtete väljendamises. Kool ühtlustab keelt, kirjandus aitab sellele kaasa ja kogu nähtuste sõnastus muutub aegamööda ühetaoliseks, raamatuliseks, milles põlissõnad vahelduvad aina kunstlikult loodud sõnadega /---/" (Vilberg 1930a). Selline nukker-emotsionaalne algus erineb teistest üleskutsetest ja aruannetest, mis olid pigem praktilis-ametlikud ja positiivse alatooniga, näiteks: „Taimedeilm on vallanud alati inimesi. Ühed taimed on arstirohuks, vähendades valu ja vaeva, teised pakuvad silmale ilu ja värvidevaheldust. Sellepärast andis inimene neile kõigile nimed, et ta võiks kõnelda omasugustega ühest või teisest tema tähelepanu äratanud taimest /---/" (Vilberg 1928b). Nagu aruandele kohane, annab Vilbaste teada, kui palju tal selleks hetkeks on materjali kogutud (vt tabel 1). Koolide juures on märgitud õpetaja nimi ja õpilaste arv. Suuremad saadetised on teele pannud Kohtla-Järve kool (29 õpilast), Silla kool (22), Valtu kool (20), Rootsiküla kool (19), Jõhvi kool (17), Anija kool (16), Narva-Jõesuu kool (16 õpilast). On näha, et kooli suurusel ja pärimust saatnud õpilaste arvul pole seost, sest väikesed külakoolid on linnamõõtu asulatega võrdsed. Eraldi noortele oli mõeldud taimenimede kogumise üleskutse ajakirjas Eesti Noorus (Vilberg 1933d).

Alates 1934. aastast kasutas Vilbaste küsimuskava kolmandat, täiendatud versiooni, mis on täies ulatuses avaldatud tema raamatutes (nt Vilberg 1934c, 1935a). Järgmine aruanne ilmus 1934. aastal, selles annavad 
tooni teist või enamatki korda materjali saatnud korrespondendid (Vilberg 1934a). See on ka arusaadav, sest nagu selgub Vilbaste käsikirjakogust, milles on säilinud tema kirjavahetus, vastas ta ka kõige väiksemale saadud teabele, kommenteeris saadetist (määras võimaluse korral taimed, märkides nii ladinakeelse kui ka eestikeelse teadusliku nime) ja tänas. Juhul kui nime määrata ei õnnestunud, palus ta saata kas täpsemaid taimekirjeldusi või herbaarlehti. Kõik tema kirjad lõppevad üleskutsega koguda saadetule veel lisa.

Pärimuse kogumise aktiivsus olenes kohaliku kooli õpetaja aktiivsusest. ERAs Vilbaste käsikirjakogus leidub kümneid vastuseid, kus kooliõpetaja vastab Vilbaste isiklikule palvele vaid seda, et kahjuks nende kandis rahvas taimi ei tunne. Kooliõpilaste saadetised saab laias laastus jagada kaheks. Rohkem on töid, mis kannavad pealkirja „Meie pool nimetatakse taimi" ja sisaldavad taimede loendit: puid, põõsaid, rohttaimi, söögitaimi jne. Nendes töödes puudub info taimede kasutamise kohta või on seda väga vähe - need tööd on saadetud esimese üleskutse peale. Teist tööde rühma iseloomustab pealkiri ,Taimede tarvitamine endisel ajal”, milles suurem rõhk on pandud taimedega arstimisele, värvimisele ja muule (nt nõidumine, taimede tarvitamine toiduks, veterinaarias, külviaegade andmed). Eraldi taimenimeloendit teise rühma saadetistele ei järgne. Selliselt vormistatud tööd olid kas ühekordsed saadetised või kui enne oli saadetud taimenimekiri, siis teist korda saadetud Vilbaste küsimise peale.

Vilbaste tunnustas ja tänas iga väiksemagi saadetise eest. Nagu selgus, andsid õpetajad tänusõnad lastele ka edasi. See andis tihti häid tulemusi, mida näitab koolist teise saadetise saamine. Alates 1930. aastast, kui hakkas ilmuma Vilbaste ajakiri Loodusevaatleja ${ }^{2}$, hakkas ta tänukirjadele värsket ajakirjanumbrit kaasa panema. Kui ta oli avaldanud mõne rahvabotaanikat sisaldava artikli, siis saatis ka selle separaadi, et näidata, kui oluline on õpilaste kogutud materjal. Tagantjärele hinnates võis sellisel toimimisel olla kolm eemärki: 1) teha reklaami oma ajakirjale, 2) innustada pärimust edasi koguma ja 3) suurendada huvi looduse vastu.

Muidugi ei jätnud Vilbaste taimenimede kogumisel kasutamata ka oma kooliõpetajaameti eeliseid: ta andis taimenimede kogumise kodutööks, see oli üks osa maateaduse ainest mõlemas Tartu gümnaasiumis, kus ta õpetaja oli. Sel moel sai ta mitme köite jagu materjali (nt Vilbaste,

2 Populaarloodusteaduslik ajakiri aastast 1930, ilmus kuus korda aastas kuni 1938. aastani, mil majanduslike raskuste tõttu lõpetas ilmumise. 
TN 5), mille maht ületas kõiki teisi koole väga suurelt, sest nagu eespool mainitud, suutsid vaid üksikud kooliõpetajad oma kodukohas pärimust koguma meelitada üle 20 õpilase ja sageli saadeti ühest koolist materjali vaid üks kord.

Hinnanguliselt pooled kogujad sai Vilbaste just isiklike pöördumiste kaudu kas kirja teel või otsekontaktidena. Kui paljudele õpetajatele ta isikliku kirja läkitas, ei oska arvata, kuid on teada, et 1929. aastal saatis Vilbaste kordusüleskutse üle 60 õpetajale, kes esimesele kirjale ei vastanud (Vilbaste, TN 1: 1118). Isikliku pöördumise kaudu sai ta korrespondentideks ka Jaak Sõggeli (1931-1934, 26 lk materjale), Theodor Saare (1937-1943, 17 lk) ja Gustav Tikerpuu (1929-1934, 20 lk), kes olid ühtlasi ka Jakob Hurda, Matthias Johann Eiseni ja Eesti rahvaluule arhiivi suurkogujad. Samuti aitasid Vilbastet Alli Vetekaja (1960-1965, kirjavahetust 115 lk), Priidu Tammepuu (1963, 161 lk), Aadu Toomesalu (alates 1940. a kuni 1960ndateni) jt Emakeele Seltsi murdekorrespondendid. Üldjuhul dubleerisid need kümned kattuvad kogujad juba varem mujale saadetut või kui taimepärimus oligi Vilbastele esimesena saadetud, siis hiljem saadeti sama materjal ka mujale. Näiteks kooliõpetaja Julius Luntsu 1931. aastal Vilbastele kogutud taimepärimus ühtib täielikult 1937. aastal ERAsse saadetuga, Alli Vetekaja läkitas Emakeele Seltsile saadetud võistlustöö koopia ka Vilbastele jne. Ka nendele suurkogujatele saatis Vilbaste oma taimeraamatuid. Jaak Sõggel küsis raamatuid ise, mille peale Vilbaste saatiski talle oma taimemääraja. Gustav Tikerpuu sai Loodusevaatleja ja nurmenuku artikli separaadi ning Alli Vetekaja raamatud „Meie kodumaa taimi rahva käsitluses", mille üle viimane väga rõõmustas jne.

Vilbaste kogus taimepärimust kuni elu lõpuni ja suhtles aktiivselt oma korrespondentidega, mille koguarv võib olla kaugelt üle 1500 (sh õpilased). See peamiselt etnobotaaniline materjal asub ERAs temanimelises kogus 11 köites (Vilbaste, TN) ja sisaldab 8319 lehekülge. Korrespondentide nimekiri on kindlasti pikem, sest tihti ei säilitanud Vilbaste kogutud pärimuse hulgas informantide andmeid, vaid kirjutas näiteks turult kogutud taimenimede juurde täpsustuseks vaid Tallinna turunaised ${ }^{3}$. Selles nimekirjas on toodud ka kirjandusest, käsikirjadest ja arhiividest saadud andmed. Iga nimekirja lehekülje all on liidetud üksikute saatjate arv kokku ja alates 1930. aastast on juurde märgitud ka liitmise kuupäev.

${ }^{3}$ Vt pikemalt selle teema kohta Loodusevaatleja nr 5, 1935, lk 155-156. 
Kui palju selles on etnobotaanilist materjali, näitavad selle põhjal tehtud registri andmed (vt tabel $\left.{ }^{4}\right)$.

\begin{tabular}{|l|c|c|c|c|c|c|c|c|c|}
\hline $\begin{array}{l}\text { Vahe- } \\
\text { aruanded }\end{array}$ & $\begin{array}{c}1 . \text { II } \\
1930\end{array}$ & $\begin{array}{c}27 . \text { XI } \\
1930\end{array}$ & $\begin{array}{c}10 . \text { XII } \\
1933\end{array}$ & $\begin{array}{c}20 . \text { I } \\
1937\end{array}$ & ERA & $\begin{array}{c}31 . \text { V } \\
1939\end{array}$ & 1944 & $\begin{array}{c}24 . \text { VI } \\
1966\end{array}$ & $\begin{array}{l}\text { Teateid } \\
\text { kokku }\end{array}$ \\
\hline $\begin{array}{l}\text { Taime- } \\
\text { kasutusi }\end{array}$ & 4562 & 6381 & 8227 & 13305 & 3129 & 14540 & 15168 & 16885 & 16891 \\
\hline $\begin{array}{l}\text { Taime- } \\
\text { nimesid }\end{array}$ & 23839 & 28228 & 31086 & 36521 & 168 & 46643 & 79966 & 100790 & 100842 \\
\hline
\end{tabular}

\section{Etnobotaanilise ainese publitseerimine alates aastast $1930^{5}$}

1930ndateks oli Vilbastel juba märkimisväärne kogu etnobotaanilist materjali ja loomuliku jätkuna hakkas ta seda publitseerima. 1932 ilmus kogumikus „Kodu ja Maailm” artikkel „Taimed arstirohuna aegade kestes” (Vilberg 1932a). Selle artikli puhul on tähelepanuväärne, et Vilbaste integreeris oma napid materjalid varem avaldatutega, nagu arsti ja kirjamehe Johann Wilhelm Ludwig von Luce (,Topographische Nachrichten von der Insel Oesel ..”, 1823), etnograafi Ilmari Mannineni („Üldjooni meie rahvameditsiinist”, 1925) ja Otto Brunfelsi („Contrafayt Kreuterbuch nach rechter vollkommener Art ..”, 1532) kirjutistega, kuid ka Gaius Plinius vanema („Historia naturalis” („Loodusteadus”) u 78. a pK) teadetega. See Vilbaste artikkel sisaldab suuri üldistusi ning seda on kerge lugeda. Järgmise aasta Eesti Kirjanduses ilmus Vilbastelt juba kaks põhjalikku etnobotaanilist artiklit. Esimese, nurmenukunimedest rääkiva artikli (Vilberg 1933a) jaoks vajaliku materjali kogumiseks pöördus ta isiklikult Eesti ärksamate inimeste - kooliõpetajate poole, kellelt küsis vaid ühte küsimust: kuidas teie pool nurmenukku kutsutakse? Ainult sellele küsimusele vastas üle 40 õpetaja üle Eesti.

4 Tabel on koostatud Vilbaste, TNi köite 1 lehekülgedel 1205-1284 oleva nimekirja põhjal. 1930ndatel liideti Eesti Rahvaluule Arhiivis olnud andmed. Viimases tulbas toodud numbrid on kogu teadete arv Gustav Vilbaste taimenimede kogus.

5 Vilbaste tähtsama loodusteaduse ja ka etnobotaanika bibliograafia on avaldanud botaanik Toomas Kukk oma raamatu „Eesti taimestik” (1999: 440-443) kirjanduse peatükis. See sisaldab kokku 175 kirjet. Käesoleva artikli jaoks on valitud taimepärimust käsitlevad artiklid. Vilbaste loodusteaduslikud ja kultuuriloolised ning käsikirja jäänud artiklid vajavad eraldi analüüsi. 
Arvatavalt rakendas ta nurmenuku puhul keelemehe Andrus Saareste keelegeograafilist meetodit, millele viitavad ka artikli mustandkaardid käsikirjas (Vilbaste, TN 1: 1195-1201). Sellise põhjaliku uurimise tulemusena on „Eesti taimenimetustes” lõpuks kirjas üle saja rahvapärase nurmenukunime, mis on Eesti puhul rekord. Miks ta selle artikli koostamisel sellist meetodit kasutas, võib vaid oletada. Ilmselt tahtis ta ühe taime kohta kiiresti kätte saada kogu võimaliku teabe, mida talle seni saadetud materjal ei võimaldanud.

Kohe järgmises ajakirjanumbris ilmunud artikkel eestikeelsete taimenimede tekkimisest (Vilberg 1933b), mis on toimetatuna ilmunud ka „Eesti taimenimetuste" (Vilbaste 1993) sissejuhatavas osas, pole kaotanud oma aktuaalsust ja tsiteeritavust ka tänapäeval. 1934. aastal ilmutas Vilbaste oma ajakirjas Loodusevaatleja artikli „Kultuurtaimi 300 aasta eest”. Selles toob ta välja, millised eestikeelsed taimenimed esinevad kolmes esimeses eestikeelses sõnaraamatus ja grammatikas ${ }^{6}$. Ta oletab, et kui on olemas võõrtaime nimi, siis järelikult ka kasvatatakse seda taime, peamiselt küll (kiriku)mõisade aedades, sest enamik kultuurtaimi, nagu Vilbaste artiklis selgitab, olid talupojale sel ajal tundmatud või kättesaamatud. Artikli eesmärk oli siiski anda hea ülevaade kultuurtaimenimede ajaloost (mõnedki neist olid grammatikakoostajate loodud, mitte rahva seas levinud nimed, vt Vilberg 1934b: 14), mitte kultuurtaimede tegelikust kasutusajaloost, sest artikli kirjutamisel on kasutatud vaid kolme grammatikaraamatut. Eesti teadusajaloolane Vaike Hang on öelnud Vilbaste artiklite arvukuse kohta, et ,,iga sündinud mõte, uurimistulemus, huvitav tähelepanek pidid kiiresti jõudma huviliste laiema ringi ette" (Hang 1985: 409-410), ja arvatavalt lähtus Vilbaste ka seda artiklit kirjutades soovist oma uusi mõtteid levitada. Samal, 1934. aastal andis ta välja esimese osa Eesti esimesest etnobotaanilisest suurteosest „Meie kodumaa taimi rahva käsitluses”. See ilmus kahe vihuna (Vilberg 1934c), järgmisel aastal ilmus teose teine osa (Vilberg 1935a). Neis kahes osas on kirjeldatud aru- ja sooniitudel kasvavaid rohttaimi. Kahjuks jäid suurteose kolm järgmist osa (puud, põõsad, metsa- ja sootaimed jne) välja andmata. Need kaks, Vilbaste oma kulu ja kirjadega välja antud põhjalikku raamatut sisaldasid iga taime kohta

6 Heinrich Stahl 1637. Anführung zu der Esthnischen Sprach, auff Wolgemeinten Rath, und Bittliches Ersuchen; Johann Gutslaff 1648. Observationes Grammaticae circa linguam Esthonicam; Henrich Göseken 1660. Manuductio ad Linguam Oesthonicam, Anführung zur Öhstnischen Sprache .. 
põhjalikku teavet: taime kasutus rahvabotaanikas meil ja mujal, rahvapärased nimed, nende tekkimine ja nendega seotud muistendid, taimes sisalduvad keemilised ühendid, taime kasutamine meditsiinis ja kultuuris. Taimeartiklid sisaldasid põhjalikku kirjeldust, joonist ja taimegeograafiat, lisaks oli esitatud selle taimeperekonna teisi, vähem tuntud liike. Esimesed kaks osa said palju positiivset tagasisidet (nt Hindrey 1934; Reeben 1934). Lisaks kirjutas Vilbaste sel ajal arvukalt väiksemaid artikleid laiale lugejaskonnale mõeldud ajalehtedesse. Näiteks jõulude ajal ilmus talt artikkel pähklite etnobotaanika kohta. Selles rääkis ta, milliseid mänge pähklitega jõuluajal mängiti, andis ülevaate sissetoodud ja müügil olevatest pähklitest ning nende botaanikast ja päritolust (Vilberg 1934d). Ajaleheartikkel oli küll lühendatud versioon paar aastat varem ilmunud artiklist (Vilberg 1932b), kuid samas sisaldas see vähem botaanikat ja rohkem etnobotaanikat. Ajalehtedes ilmus Vilbaste artikleid küllaltki tihti, näiteks 1935. aastal kaks ülevaateartiklit Eesti nõidustaimedest (Vilberg 1935b, 1935c), kuid Vilbaste lõpetas selle artikliseeria tõdemusega, et nõidustaimede kasutamine ei too kellelegi õnne. Nõidustaimedele vastukaaluks esines ta Akadeemilise Rahvaluule Seltsi koosolekul ettekandega „Kust leida õnne. Taimed õnne-ennustajatena ja tulevikukuulutajatena”. Sellest ilmus ka ajakirjaniku poolt refereeritud artikkel ajalehes, mahtudes ajaliselt kahe nõidustaimeartikli vahele (Postimees 1935). Õnne- ja ennustustaimedest kirjutas Vilbaste teadusartikli Eesti Rahva Muuseumi aastaraamatusse (Vilbaste-Vilberg 1936). Selles selgub, et eestlased tunnevad kõige laiemalt õnneennustajana jaani-õnneheina (lad Erigeron acer), mille kasutust mujal ei tunta, kokku kirjeldab Vilbaste kaheksat taime või taimesaadust. Ajalehtedes ja ajakirjades avaldas Vilbaste ka arvukalt lühemaid, ühe taime kohta käivaid või ühte etnobotaanilist teemat käsitlevaid artikleid (nt Vilbaste 1933c $\mathrm{c}^{7}, 1935 \mathrm{~d}$ ).

Vilbaste laiemat huvi taimede ja inimeste vaheliste suhete vastu näitab kahe artikli avaldamine tema oma ajakirjas. Esimeses artiklis „Taimed ja taimeühingud vanasõnades" (1937) analüüsib Vilbaste F. J. Wiedemanni ja M. J. Eiseni raamatutes avaldatud ja tema enda kogus leiduvaid, seni avaldamata vanasõnu. Teine, aasta hiljem ilmunud artikkel käsitleb taimi mõistatustes (Vilbaste 1938a). Seal esitab Vilbaste samuti M. J. Eiseni raamatust pärinevaid taimemõistatusi, mis käivad 35 taime või taime-

7 Sama sisuga ilmus see artikkel ajalehes Postimees juba 1918. aastal (Vilberg 1918). 
ühingu kohta. Vilbaste märgib, et kõige rohkem on Eestis mõistatusi pähkli, herne, humala, kapsa, maasika, läätse, lina, jõhvika ja oa kohta, öeldes, et artiklis toodud näitemõistatused nende taimede juures on vaid murdosa nende koguarvust.

Muidugi ei jätnud Vilbaste oma uurimustes puudutamata taimedega värvimist, millest ilmus teadusartikkel Eesti Rahva Muuseumi aastaraamatus (1938b). Seal on ära toodud kõik Eesti taimestiku ja kultuurtaimede (sh samblikud) võimalused eri materjalide värvimiseks, värvimistehnoloogia, värvitoonid, peitsid jne. Uurimuse jaoks oli Vilbaste läbi töötanud nii kirjanduse kui ka oma etnobotaanilise kogu. See uurimus pole tänaseni oma väärtust kaotanud ja on üks tähtsamaid sellealaseid töid Eestis.

Vilbaste sai Eesti taimenimede raamatu parandamiseks ja täiendamiseks tööstipendiumi Õpetatud Eesti Seltsist (ÕES) ja Loodusuurijate Seltsist (LUS). Nendega rahastas ta osaliselt 1942.-1943. aasta suvedel oma üle-eestilisi välitöid, mille kuludest enamiku kattis ta siiski ise. Välitööde eesmärk oli kontrollida ja kindlaks määrata talle saadetud taimenimesid. Sõjaaja tõttu oli tal vaja asjakohaste ametkondade luba Eestit mööda ringisõitmiseks. Vilbaste liikles enamasti ratta või bussiga. 1942. a sõitis ta läbi $2373 \mathrm{~km}$ ning sai juurde 9520 nime ja 99 kasutust, 1943. a läbis ta 2064 km ning kogus 14942 nime ja 223 kasutust (aruanne ÕESile ja LUSile). Raamatu „Rahvapäraseid taimenimesid Eesti NSV-s” sai ta käsikirjana valmis 1944. aastaks.

\section{Keele- ja pärimusuurija pärast II maailmasõda}

Kuigi Vilbaste sai oma monograafia käsikirja valmis, puudus sõja ajal võimalus selle väljaandmiseks ning ta täiendas seda veel kuni 1950ndate keskpaigani, mil Emakeele Seltsi abiga tehti algkäsikirjast viis masinkirjakoopiat. Need kannavad tiitellehel aastaarvu 1960. Üks eksemplar asub ERAs Vilbaste-nimelises fondis (Vilbaste, T8-T10) ja sisaldab $1227+54$ masinakirjalehekülge. 1959. aastal moodustati Emakeele Seltsi initsiatiivil komisjon tunnustatud keele- ja loodusteadlastest, kes hakkasid omast ajast seda mahukat käsikirja toimetama. 1961. aastal saadi üheksa kuu vältel kasutada ka ajutist palgatööjõudu. Käsikiri osutus keerulisemaks, kui algul arvatud, ja toimetamistöö venis üle kolmekümne aasta pikaks. Raamat ilmus alles 1993. aastal. Selles töös osales läbi aegade üle 20 tunnustatud Eesti teadlase. Mida ja kui palju käsikirjast parandati, ei oska 
tagantjärele enam keegi öelda. Suuremad täpsustused ja parandused, mida toimetajatest komisjon tegi, on raamatu esimestes peatükkides kokku võtnud raamatu peatoimetajad keeleteadlane Heino Ahven ja loodusteadlane akadeemik Erast Parmasto (Vilbaste 1993: 7-14). Toimetajate otsusel jäeti käsikirjast välja teistelt Eestis elavatelt rahvastelt (venelased, sakslased, lätlased, rootslased, soomlased, mustlased ja juudid ${ }^{8}$ ) ja eesti hõimlastelt (soomlased, isurid ja vadjalased ${ }^{9}$ ) kogutud taimenimed, sest nende ülekontrollimine oleks raamatu ilmumist veelgi edasi lükanud. Selle materjali kõrval pole kunagi trükki jõudnud Vilbaste kogutud seene-, sambla-, sambliku- ja vetikanimed, mille nimekiri asub Emakeele Seltsis ja ERAs (Vilbaste, T6).

Vanaduspensionil olles pöördus Vilbaste tagasi noorusharrastuse juurde, milleks oli rahvaluule ning keele kogumine ja uurimine Kuusalu kihelkonnas. Tähtsamateks välisekspeditsioonideks kujunesid retked NSVLi sisealadel elavate eesti hõimlaste juurde. 1956. aastal kutsus akadeemik Paul Ariste teda Leningradi oblastisse läänemeresoome sugulasrahvaste vadjalaste ja isurite asualale. Sellele järgnes Emakeele Seltsi aastaraamatus ülevaade (Vilbaste 1957a), mis sisaldas kogutud taimenimesid ja muud vadjakeelset botaanilist sõnavara. Isurikeelsete taimenimede käsikiri (362 lk) asub nii Emakeele Seltsis kui ka ERAs, uurimuse tiitellehel on aastaarv 1956 (Vilbaste, T6). 1956. aastal avaldas Vilbaste mahuka uurimuse Emakeele Seltsi aastaraamatus pealkirjaga „Rahvapäraste taimenimede kogumise katseid möödunud sajanditel" (Vilbaste 1956). Selles nendib ta tõsiasja, et erksamad külainimesed Eestis tundsid XX sajandi esimesel poolel vähemalt 200-250 taime. Artikli eesmärk oli siiski anda ülevaade eestikeelsete taimenimede esinemisest baltisakslastest autorite töödes XVII sajandist kuni XX sajandini, autorite seosest botaanikaga ning taimenimede muutustest ja tekkest nende kirjutistes ${ }^{10}$. Mitmete Eesti kultuuris oluliste tegelaste seostest (etno)botaanikaga on Vilbaste kirjutanud eraldi artiklites (nt Vilberg 1932c, 1932d).

1957. aastal ilmus Vilbaste uurimus rahvuseeposes „Kalevipoeg” leiduvate taimede kohta. Peale puude, põõsaste ja rohttaimede nimetuste

${ }^{8}$ Käsikirjad asuvad nii Emakeele Seltsis kui ka ERAs, tiitellehel on aastaarv 1953 (Vilbaste, T3).

9 Ka need käsikirjad asuvad ERAs ja Emakeele Seltsis.

${ }^{10}$ Toimetatuna on artikkel avaldatud ka tema „Eesti taimenimetuste” üldosas (Vilbaste 1993). 
on esitatud ka teisi botaanikamõisteid (Vilbaste 1957b). Selle käsikirjaline algmaterjal (maht 46 lk) kannab tiitellehel aastaarvu 1952 ja asub samuti ERAs (Vilbaste, T4) ${ }^{11}$.

Järgnevalt (1959. aastal, olles ise juba 74 aastat vana) võttis Vilbaste omal käel ette välisekspeditsiooni Põhja-Kaukaasia eestlaste asualadele, kus uuris Kaukaasia eestlaste sõnavara. Ta tõdes enne reisi, et „Eestimaa on palju kordi risti-põiki läbi sõidetud, aga Kaukaasia eestlaste juurde pole veel saanud! Tuleb minna!” (Ahven 1968). Sellest ekspeditsioonist tegi ta hiljem Emakeele Seltsis ettekande, mille põhjal avaldas ka seltsi aastaraamatus artikli (Vilbaste 1960). Emakeele Seltsile üleantud mahukas uurimus Kaukaasia eestlastest ei sisaldanud mitte ainult välitöödel saadud materjali, vaid ka läbitöötatud kättesaadavat trükisõna, arhiivimaterjale ja Vilbaste isiklikku kirjavahetust. Selle uurimuse käsikiri asub ERAs (Ahven 1965, 1968).

Vilbaste pensionipõlve tähtsaimaks raamatuks saab pidada ainsat nõukogude ajal ilmunud ravimtaimeraamatut, mille ta andis välja koos farmatseut Oskar Koogiga 1962. aastal (Kook, Vilbaste 1962). Selles raamatus tuuakse iga taime juures ka tähtsamad rahvapärased nimed ja kasutus rahvameditsiinis. Seda raamatut anti välja kokku viis kordustrükki, kusjuures alles viiendas trükis on avaldatud eelmistest välja jäänud, ametlikus meditsiinis mittetunnistatud ravimtaimed (Tammeorg jt 1984). Käesoleva artikli autorid väidavad, et enamik seal avaldatud arvukatest rahvapärasetest nimedest olid tolleks ajaks juba rahva keelest ja meelest kadunud, kuid tänu raamatu ilmumisele leidsid need taas koha rahva sõnavaras.

\section{Lõpetuseks}

Vilbaste kogumistöö algus langeb kokku ajaga, mil noor linnaharitlaskond hakkas väärtustama vanavara ja selle kaudu otsima oma juuri, hakates käima peamiselt stipendiaatidena välitöödel rahvaluulet kogumas. Maarahvas suhtus samas rahvaluule kogumisse põlgusega ja kogujatega tihti kontakti ei leidnud. Vilbaste eristus kohalikest selle poolest, et oli haritlane, õpetaja, ning teistest kogujatest selle poolest, et elas kogukonnas, mis aitas tal tol ajal parimat tulemust saavutada. Järgmistel eluetappidel

${ }^{11}$ Lisaks on Vilbaste läbi uurinud eesti rahvalauludes esinevad taimenimed. Materjal asub ERAs köites Vilbaste, T5 (tiitellehel on aastaarv 1953, maht 104 lk). 
muutus tema erakordne allikmaterjali hankimise metoodika ja analüüsioskus järjest paremaks.

Vilbaste panus eesti botaaniliste murdesõnade kogumisse ja uurimisse on hindamatu. Kuigi ta oli enamiku aja oma elust lihtne kooliõpetaja, muutsid tema botaanika- ja etnobotaanikaalased teaduslikud ja populaarteaduslikud artiklid vähemalt ühe põlvkonna eestlaste vaateid. Viktor Masing on öelnud, et keeleinimesed poleks nõnda suutnud tajuda nende botaanikasõnade tähendust, nagu suutis botaanikuharidusega murdeuurija Vilbaste. Kuigi ta kogus taimenimesid kuni oma elupäevade lõpuni, teadis ta selle töö lõppematust, mida näitab ka viimase üleskutse ilmumine pärast tema surma (Vilbaste 1968). Taimenimede uurimine pakub siiski ka huvi keeleinimestele, mida näitavad viimasel ajal ilmunud teadusartiklid (Oja 2007a, 2007b) ning võib loota, et ka Vilbaste käsikirjakogu leiab põhjalikumat uurimist nii folkloristide kui ka keeleinimeste poolt. Seni raskendab seda registrite puudumine. Lõpetuseks sobib tsitaat Viktor Masingult: „Tal õnnestus korrespondentide abiga viimasel hetkel, kadumise eel fikseerida suur osa eestlaste taimeteadmisi, kuigi palju oli ka alatiseks kaotsi läinud nagu ajaloos ikka. Kui praegu keegi soovikski vanaaegseid taimetarkusi rahva seas leida ja koguda, poleks see enam võimalik. Vana rahvapärand on kadunud koos rahvaliku taimetundmisega, mida kunagi maal põlvest põlve edasi anti. Meie praegused vanimadki inimesed on saanud oma teadmised taimede kohta koolist või töökohast, arstilt või apteekrilt, eriti aga raamatuist, raadiost ja muudest massiteabeallikaist, ja kõik see on maha surunud ja moonutanud suulist pärandit seal, kus see oli veel elav. /---/ Paljudel rahvastel, kel pole olnud oma Vilbastet, on seetõttu päästmatult kaotsi läinud ka taimetarkus kui oluline osa kunagisest elutundmisest ja maailmanägemisest” (Masing 1985: 599).

Artikkel on lühendatud versioon Gustav Vilbastele pühendatud peatükist lähiajal ilmuvas ingliskeelses raamatus „Pioneers in european ethnobiology (Uppsala: Royal Gustavus Adolphus Academy; toimetajad Ingvar Svanberg ja Lukasz Luczaj). Autorid tänavad kahte anonüümset retsensenti ja Mati Ereltit põhjalike kommentaaride eest, mis aitasid artiklit paremaks muuta, ning Tuul Seppa artikli algversiooni ja Sirje Mäearu lõpliku versiooni keelelise toimetamise eest. 


\section{Kirjandus}

Ahven, Heino 1965. Üle üheksanda aastakümne raja. - Kodumurre 7. Toim. Heino Ahven. Eesti NSV Teaduste Akadeemia Emakeele Selts. Tallinn, 5-7.

Ahven, Heino 1968. Gustav Vilbaste. In memoriam. - Emakeele Seltsi aastaraamat 13 (1967). Eesti NSV Teaduste Akadeemia Emakeele Selts. Tallinn: Eesti Raamat, 255-260.

Hang, Vaike 1985. Armastada elu. - Eesti Loodus 6, 408-411.

Hiiemäe, Mall 2005. Endis-Eesti elu-olu aspekt G. Vilbaste väärtushinnangutes. Loodusteaduste ja looduspärimuse vahel: Gustav Vilbaste 120. sünniaastapäevale pühendatud konverents 16.-17.09.2005 Tartu-Kuusalu. Kava ja teesid. Korraldajad ELUSi Jakob von Uexkülli Keskus, EKM Eesti Rahvaluule Arhiiv. Toim. Mall Hiiemäe. Tartu: Eesti Kirjandusmuuseum; http://www.folklore.ee/era/uudis/vilbaste.htm\#oras.

Hindrey, Karl August 1934. Teadusliku Teose esimene vihik. Dr. phil. G. Wilberg. Meie kodumaa taimi rahva käsitluses. Loodusvaatleja kirjastus Tartus. Postimees 4. VIII.

Kook, Oskar, Gustav Vilbaste 1962. Eesti NSV ravimtaimed. Tallinn: Eesti Riiklik Kirjastus.

KT 1917 = Kodumaa taimed. Koost. Eesti Üliõpilaste Seltsi Loodusteaduste Osakond, Eesti Kirjanduse Seltsi Keeletoimkond. Tartu: Eesti Kirjanduse Selts.

KT 1918 = Kodumaa taimed. 1. jagu: Õistaimed. Koost. E.Ü.S. Loodusteaduse Osakond, E.K.S. Keeletoimekond. (= Eesti Kirjanduse Seltsi Keeletoimekonna toimetused nr. 6a.) Tartu: Eesti Kirjanduse Selts.

Kukk, Toomas 1999. Eesti taimestik. (= Eesti looduse mitmekesisus 2.) Eesti Põllumajandusülikooli Zooloogia ja Botaanika Instituut, Eesti Keskkonnaministeerium, ÜRO Keskkonnaprogramm. Tallinn: Teaduste Akadeemia Kirjastus.

Laasimer jt 1994 = Liivia Laasimer, Mall Hiiemäe, Aleksei Peterson, Heino Ahven. Gustav Vilbaste elu ja tegevus. - Botaanika ajaloost Eestis. Vastutav toimetaja Viktor Masing. (= Teaduse ajaloo lehekülgi Eestis, 10. kogumik.) Eesti Loodusuurijate Selts Eesti Teaduste Akadeemia juures, Teadusajaloo ja Teadusfilosoofia Eesti Ühendus. Tallinn: Teaduste Akadeemia Kirjastus, 43-57.

Masing, Viktor 1985. Ajas vääristatult. - Eesti Loodus 9, 595-599.

Mäger, Mart 1967. Gustav Vilbaste 3. sept. 1885-21.veebr. 1967. - Kodumurre 8. Eesti NSV Teaduste Akadeemia Emakeele Selts. Toim. Heino Ahven. Tallinn: Emakeele Selts, 119-121.

Nenjukov, Theodor (koost.) 1928. Eesti taimede nimestik. Index plantarum estonicarum. Botaanika oskussõnade komisjon. 2., ümbertöötatud trükk. Tartu: Eesti Kirjanduse Selts. 
Oja, Vilja 2007a. Kasulikul taimel on rohkesti nimesid. - Прибалтийскофинское языкознание: лингвогеографические исследования. Сост. Нина Г. Зайцева. Карельский научный центр. Российская академия наук. Институт языка, литературы и истории. Петрозаводск: Карельский научный центр РАН, 58-75.

Oja, Vilja 2007b. Ratamo; teeleht. - Atlas Linguarum Fennicarum ALFE. 2. Itämerensuomalainen kielikartasto. Läänemeresoome keeleatlas. Ostseefinnischer Sprachatlas. Лингвистический атлас прибалтийскофинских языков. Päätoim. Tuomo Tuomi, 2. osan vastaava toimittaja Tiit-Rein Viitso. Kartat: Anneli Hänninen; saksankielinen käännös: Klaas Ph. Ruppel, venäjänkielinen käännös: Vladimir Rjagojev, Nina Zaitseva, vironkielinen käännös: Helmi Neetar. (= Suomalaisen Kirjallisuuden Seuran toimituksia 800, Kotimaisten kielten tutkimuskeskuksen julkaisuja 118.) Helsinki: Suomalaisen kirjallisuuden seura, Kotimaisen kielten tutkimuskeskus, 98-105.

Oras, Janika 2006. Gustav Vilbaste „rahva ja luule vahel”. - Eesti Üliõpilaste Seltsi pärimusekogujana aastatel 1908-1916. - Paar Sammukest. Koost. Mall Hiiemäe, toim. Ergo-Hart Västrik. (= Eesti Kirjandusmuuseumi aastaraamat 2005.) Tartu: Eesti Kirjandusmuuseum, 191-218.

Postimees 1907. Teateid Tartust. Üleskutse. Eesti Üliõpilaste Selts. 21. aprill.

Postimees 1912. Taimeteaduse oskussõnade asjus. Eesti Üliõpilaste Selts. 26. november.

Postimees 1923. Taimede rahvapäraste nimede kogumine. 2. juuni.

Postimees 1935. Kust Leida õnne. Taimed õnne-ennustajatena ja tulevikukuulutajatena. (Dr. G. Vilbergi ettekande referaat Akadeemilise Rahvaluule Seltsi koosolekul peetud ettekandest). 6. mai.

Reeben, August 1934. Dr. phil. G. Vilberg, Meie Kodumaa taimi rahva käsitluses I. Loodusevaatleja kirjastus. Tartu, 1934. 128 lk. Hind 2 krooni. - Loodusevaatleja 5, 154.

Svanberg jt 2011 = Ingvar Svanberg, Łukasz J. Łuczaj, Manuel Pardo-de-Santayana, Andrea Pieroni. History and Current Trends of Ethnobiological Research in Europe. - Ethnobiology. Ed. E. N. Anderson, Deborah Pearsall, Eugene Hunn, Nancy Turner. Chichester, UK: Wiley-Blackwell, 191-214.

Tammeorg jt 1984 = Johannes Tammeorg, Oskar Kook, Gustav Vilbaste. Eesti NSV ravimtaimed. 5., täiendatud ja parandatud trükk. Tallinn: Valgus.

Vilbaste, Gustav 1935. Tartu turul müüdavad arstirohutaimed. - Loodusevaatleja $5,155-156$.

Vilbaste, Gustav 1937. Taimed ja taimeühingud vanasõnades. - Loodusevaatleja 4, 114-116.

Vilbaste, Gustav 1938a. Taimed mõistatustes. - Loodusevaatleja 1, 43-47. 
Vilbaste, Gustav 1938b. Taimedega värvimisi Eestis. - Eesti Rahva Muuseumi Aastaraamat XIV, 1-56.

Vilbaste, Gustav 1956. Rahvapäraste taimenimede kogumise katseid möödunud sajanditel. - Emakeele Seltsi aastaraamat II (1956). Toim. Paul Ariste. Eesti NSV Teaduste Akadeemia Emakeele Selts. Tallinn: Eesti Riiklik Kirjastus, 195-216.

Vilbaste, Gustav 1957a. Vadja taimenimesid. - Emakeele Seltsi aastaraamat III (1957). Tallinn, 173-179.

Vilbaste, Gustav 1957b. Taimenimed „Kalevipojas”. „Kalevipoja küsimusi”. Эпос „Калевипоэг”-- Tartu Riikliku Ülikooli Toimetised. Ученые записки Тартуского государственного университета. Vihik nr 53. Vastutav toimetaja Eduard Laugaste. Tartu: Tartu Riiklik Ülikool 163-194.

Vilbaste, Gustav 1960. Kaukaasia eestlaste keelest ja rahvaluulest. - Emakeele Seltsi aastaraamat VI (1960). Tallinn, 121-131.

Vilbaste, Gustav 1962. Millised taimenimed esinevad teie kodumurdes? - Kodumurre 3/4. Toim. Heino Ahven. Tallinn: Eesti NSV Teaduste Akadeemia Emakeele Selts, 100-104.

Vilbaste, Gustav 1965. Esimesed sammud keelelisel huvialal. Peatükk mälestustest. - Kodumurre 7. Toim. Heino Ahven. Tallinn: Eesti NSV Teaduste Akadeemia Emakeele Selts, 8-12.

Vilbaste, Gustav 1968. Rahvapärasest botaanikast. - Rahvapärimuste koguja 6. Toim. Herbert Tampere, Ellen Liiv. (= Kirjandusmuuseumi kogumistöö juhendaja nr. 6.) Tartu: Eesti NSV Teaduste Akadeemia Fr. R. Kreutzwaldi nimeline Kirjandusmuuseum, 52-58.

Vilbaste, Gustav 1993. Eesti taimenimetused. Nomina vernacula plantarum Estoniae. Toim. Eeva Ahven, Heino Ahven, Erast Parmasto, Eevi Ross. (= Emakeele Seltsi toimetised 20 (67).) Tallinn: ETA Emakeele Selts.

Vilbaste-Vilberg, Gustav 1936. Õnne- ja ennustustaimi. - Eesti Rahva Muuseumi Aastaraamat XI, 36-43.

Vilberg, Gustav 1915a. Atru, adru. - Eesti Kirjandus X: 2, 55.

Vilberg, Gustav 1915b. Veel adrust. - Eesti Kirjandus X: 12, 400-402.

Vilberg, Gustav 1918. Kasemahl. - Postimees 1. V.

Vilberg, Gustav 1922. Eesti taimestik koolidele. Schmeil-Fitscheni „Flora von Deutschland" järele Eesti taimestiku kohaselt ümber töötanud G. Vilberg. Tartu: Loodus.

Vilberg, Gustav 1923a. Üleskutse Vikerlastele. Koguge taimede rahvapäraseid nimesid! - Vikerkaar 6/7, 279-280.

Vilberg, Gustav 1923b. Koguge taimede rahvapäraseid nimesid. - Eesti Mets 7, $130-131$.

Vilberg, Gustav 1923c. Koguge taimede rahvapäraseid nimesid! - Loodus 5, 320 . 
Vilberg, Gustav 1923d. Koguge taimede rahvapäraseid nimesid! - Kasvatus 6, 191.

Vilberg, Gustav 1925. Eesti taimestik: Koolidele: Abiraamat taimede tundmaõppimiseks. Tartu: Loodus.

Vilberg, Gustav 1928a. Koguge taimede rahvapäraseid nimesid! - Eesti Keel $1 / 2,32$.

Vilberg, Gustav 1928b. Koguge taimede rahvapäraseid nimesid! - Eesti Kirjandus 5, 287.

Vilberg, Gustav 1928c. Koguge taimede rahvapäraseid nimesid! - Postimees 6.VI.

Vilberg, Gustav 1928d. Koguge taimede rahvapäraseid nimesid! - Päevaleht 7. VI.

Vilberg, Gustav 1928e. Koguge taimede rahvapäraseid nimesid. - Noorusmaa: Eesti noorsoo ajakiri. III: 5/6, 170.

Vilberg, Gustav 1928f. Kui palju tuntakse külades taimi? - Noorusmaa: Eesti noorsoo ajakiri. III: 5/6, 170-172.

Vilberg, Gustav 1929a. Osa vanavara kadumas. - Eesti Mets 4/5, 110.

Vilberg, Gustav 1929b. Osa vanavara kadumas. - Postimees 3. IV.

Vilberg, Gustav 1930a. Aruanne rahvapäraste taimenimede kogumisest. - Eesti Kirjandus 2, 95-96.

Vilberg, Gustav 1930b. Aruanne rahvapäraste taimenimede kogumisest. - Postimees 10. II.

Vilberg, Gustav 1932a. Taimed arstirohuna aegade kestes. - Kodu ja Maailm. Suvealbum 1932. Tartu: Karskuse Sõbra Kirjastus, 15-18.

Vilberg, Gustav 1932b. Pähklid jõululaual. - Loodusevaatleja 6, 172-179.

Vilberg, Gustav 1932c. J. H. Rosenplänter taimeteadlasena. - Äratrükk „Olionist” 5/6, 1931 ja 5/6, 1932. Tartu: Postimees.

Vilberg, Gustav 1932d. Fr. R. Kreutzwaldi taimeteaduslikke harrastusi. Loodusevaatleja 3, 129-133.

Vilberg, Gustav 1933a. Nurmenuku nimesid Eestis. - Eesti Kirjandus XXVI: $6,275-280$.

Vilberg, Gustav 1933b. Eestikeelsetest taimenimedest ja nende tekkimisvõimalusist. - Eesti Kirjandus XXVII: 7, 339-347.

Vilberg, Gustav 1933c. Kevadine mahlajooks kasest. - Loodusevaatleja 2, 49-51.

Vilberg, Gustav 1933d. Ülesandeid noortele rahvapäraste taimenimede asjus. Eesti Noorus 3.

Vilberg, Gustav 1934a. Kolmas aruanne rahvapäraste taimenimede kogumisest. Loodusevaatleja 1, 32.

Vilberg, Gustav 1934b. Kultuurtaimi 300 aasta eest. - Loodusevaatleja 1, $12-14$. 
Vilberg, Gustav 1934c. Meie kodumaa taimi rahva käsitluses. I. (2 osas). Tartu: Loodusevaatleja. 1-128.

Vilberg, Gustav 1934d. Jõulu pähklid. Kasvavad puude ja põõsaste otsas: ka mullas. - Postimees 23. XII.

Vilberg, Gustav 1935a. Meie kodumaa taimi rahva käsitluses. II. Tartu: Loodusevaatleja, 129-256.

Vilberg, Gustav 1935b. Taimed, millega nõiuti. Lilli ja puid kasutati ennevanasti nõiduse arstimiseks. - Ungrukollaga arstiti kõike halba, mis oli tekkinud nõidusest. - Postimees 20. I.

Vilberg, Gustav 1935c. Liivatee paneb naist võtma. Kadakal ja pihlakal on imettegevad võimed. - Kasekoore jahu sunnib ,järel käima". - Nõidustaimed aitavad valgustada eesti vanausundit. - Postimees 2. IV.

Vilberg, Gustav 1935d. Näsiniin on mürgine taim. Nekrutid tegid sellega ,haigust" , mida vene arstid ei tundnud. - Hambavalurohi, jooksva vastu vann jne. - Näsiniin külviaja ennustaja. - Postimees 9. VII.

\section{Käsikirjad}

Aruanne ÕESile ja LUSile $=$ Aruanne rahvapäraste taimenimede korjamise üle kodumaal 1942 a. suvel 1943 a. suvel 1 X 1942 - 27 XI1 1943. Fond 152, G. Vilbaste. M 67: 4. Asub Eesti Kirjandusmuuseumi Eesti kultuuriloolises arhiivis.

Vilbaste, Gustav 1950. Oma töö sihtidest. 2. Fond 152, G. Vilbaste. M 139: 5, 1. Asub Eesti Kirjandusmuuseumi Eesti kultuuriloolises arhiivis.

Vilbaste $=$ Gustav Vilbaste rahvaluulekogu. $\mathrm{TN}$ (taimenimed) ja $\mathrm{T}$ (teosed). 1907-1966. Asub Eesti Kirjandusmuuseumi Eesti rahvaluule arhiivis. 


\title{
Gustav Vilbaste as a collector, researcher, and publisher of ethnobiological data
}

\author{
Raivo Kalle, Renata Sõukand
}

Gustav Vilbaste (1885-1967, until 1935 Vilberg), the first Estonian ethnobiologist and nature conservationist, made a remarkable contribution to the development of Estonian botanical language. However, until now little attention has been paid to his work related to the establishment of ethnobotany as a science in Estonia. He lived at a time when Estonian scientific plant names were established on the basis of vernacular names, and many traditional names were still used by people. He helped the committee on plant names by collecting vernacular names and continued this work even later. In fact, he was the only Estonian expert in this area in Estonia; judging by the value of his collections, it was an outstanding achievement also from a global perspective. Before his study of natural sciences at the University of Tartu he intensively collected general folklore, mostly folk songs, with some emphasis on ethnobotanical data. Starting from the 1920s, he collected ethnobotanical data with the help of a network of correspondents all over Estonia, including schoolchildren. After his retirement in the 1950s he resumed collecting general folklore, but also conducted several expeditions outside Estonia in order to collect data on plant names and the use of plants among the kindred peoples. His manuscript collection on vernacular plant names and the use of plants amounts to over 8,000 pages. It reflects almost 40 years of work by almost 1,500 correspondents, and it contains more data on folk plant names and the use of plants than any other folklore collection at the Estonia Folklore Archives.

Keywords: Estonian language, dialect collection, ethnobotany, plant names

Raivo Kalle

folkloristika osakond

Eesti Kirjandusmuuseum

Vanemuise 42

51003 Tartu

raivo@folklore.ee
Renata Sõukand

folkloristika osakond

Eesti Kirjandusmuuseum

Vanemuise 42

51003 Tartu

renata@folklore.ee 